\title{
Modern Fungicides: Mechanisms of Action, Fungal Resistance and Phytotoxic Effects
}

\author{
Ekaterina V. Baibakova ${ }^{1^{*}}$, Elena E. Nefedjeva ${ }^{1}$, Małgorzata Suska-Malawska ${ }^{2}$, \\ Mateusz Wilk ${ }^{2}$, Galina A. Sevriukova ${ }^{1}$ and Vladimir F. Zheltobriukhov ${ }^{1}$ \\ ${ }^{1}$ Industrial Ecology and Life Safety, The Faculty of Technology of Food Production, Volgograd State \\ Technical University, Volgograd, Russian Federation. \\ ${ }^{2}$ Faculty of Biology, Biological and Chemical Research Centre, University of Warsaw, Warsaw,
} Poland.

Authors' contributions

This work was carried out in collaboration among all authors. All authors read and approved the final manuscript.

Article Information

DOI: 10.9734/ARRB/2019/v32i330083

Editor(s):

(1) Dr. Bechan Sharma, Department of Biochemistry, University of Allahabad, Allahabad, India. (2) Prof. George Perry, Dean and Professor of Biology, University of Texas at San Antonio, USA. Reviewers:

(1) Liamngee Kator, Benue State University, Nigeria. (2) Douira Allal, Ibn Tofail University, Kénitra, Morocco. Complete Peer review History: http://www.sdiarticle3.com/review-history/49787

Review Article

Received 17 April 2019

Accepted 22 June 2019 Published 05 July 2019

\begin{abstract}
The establishment of safe and effective methods for controlling fungal diseases is an urgent issue in agriculture and forestry. Fungicide research has provided a wide range of products with new modes of action. Extensive use of these compounds in agriculture enhances public anxiety due to the harmful potential for the environment and human health. Moreover, the phytotoxic effects of some fungicides are already recognized but still little is known about their influence on the photosynthetic apparatus and plant physiology. This review provides an understanding of the mechanisms of action of fungicides, mechanisms of fungicide resistance development, and the phenomenon of phytotoxicity.
\end{abstract}

Keywords: Contact fungicides; systemic fungicides; disease control; resistance.

${ }^{*}$ Corresponding author: E-mail: ekaterina.baybakova@yandex.ru; 


\section{ABBREVIATIONS}

$\begin{array}{ll}\text { ANN } & : \text { Artificial Neural Network } \\ B P N N & : \text { Back-propagation Neural Network } \\ \text { RBF } & : \text { Radial Basis Function Networks } \\ \text { PSII } & : \text { Photosystem II } \\ \text { AMF } & : \text { Arbuscular Mycorrhizal Fungi }\end{array}$

\section{INTRODUCTION}

Fungicides are chemical substances used for control and treatment of fungal diseases of plants. The employment of fungicides has become widespread in recent decades in agriculture since it was estimated that fungal infections reduce yields of the crops worldwide by nearly $20 \%$ [1]. Fungicides have become the primary means of fungal disease control due to their relatively low cost, ease of use and efficiency [2].

Disease management is an essential component of production for all crops, often having a significant economic impact on their yield and quality. There are three main reasons for using fungicides:

- To control the infection during the establishment and growth of a grain crop;

- To enhance the productivity of cereal and to decrease defects.

Infection may result in a decrease in productivity due to the damage to photosynthetic parts. Defects in the edible parts of the crop or leaves of ornamentals affect their attractiveness, and consequently the market prices;

- To improve the shelf life and quality of produced and harvested plants.

Some of the significant disease damage occurs post-harvest. Harmful fungi often worsen stocks of grain crops, vegetables, and tubers. Several grain-infecting species of Fusarium, Penicillium or Aspergillus produce important mycotoxins which can cause serious illness or even death in humans and animals after eating contaminated food [3]. Fungicides have been used to decrease mycotoxin contamination of wheat affected by Fusarium head blight, but most fungicides developed so far have not been entirely adequate for the regulation of mycotoxin production associated with other diseases [4]. This is due to insufficient knowledge of the protectants mechanisms action and the response of the plant.
The appearance of new strains of fungal pathogens and their resistance to the available commercial products is often associated with extensive use of these compounds [5]. What is more, the widespread and frequent use of fungicides in plant protection generates a longterm accumulation of residues in food and the environment $[6,7]$. In the Report on the pesticide residues monitoring programme in 2017, analyzing vegetables and fruits from 27 countries for contamination with pesticides has shown that dithiocarbamates are among the most common residual contaminants. Accordingly, the excessive use of such compounds in agriculture gave rise to public concerns because of the detrimental effects on the environment and risk for human health [6].

For example, the fungicide chlorothalonil - the most common synthetic fungicide in the United States - was shown to be toxic to aquatic animals such as tadpoles, oysters, or fish [8].

In some cases, fungicides derived from "natural" sources are much safer than synthetic. The primary sources include copper, sulphur, plant oils and bicarbonates. But even copper can be skin irritating, eyes and the respiratory and digestive tracts, while sulphur can result in dermatitis and diarrhea [9]. To use any fungicide safely and efficiently, one needs to correctly diagnose the problem and choose the best treatment strategy.

\section{CLASSIFICATION OF FUNGICIDES}

Fungicides are often classified as protective or system. Protective fungicides are usually effective against a range spectrum of fungi and protect the plant from infection on leaf surface and stems. They often require repeated application during the growing season to provide coverage as new plants appear. Systemic fungicides can be absorbed by the plant without damage and be transported to other tissues where they are toxic to fungi. These compounds can control and fight infections, but they are also vulnerable to resistance to fungi, as they usually target only one step, to kill the fungus. To reduce resistance due to excessive use of chemicals, the fungicides are classified according to their chemical class. By alternating between different classes of fungicides the fungal population is less likely to develop resistance to a particular chemical [10].

Chemically, organic molecules always contain carbon atoms in their structure while most 
inorganic molecules do not. Initially, first fungicides were inorganic compounds based on sulphur or metal ions (copper, tin, cadmium, mercury) that are known to be toxic to fungi. Currently, fungicides based on copper and sulphur are still widely used. Copper sulphate has been registered for use in the United States since 1956. The copper atom binds to proteins, changing their structure. This may break the membranes around the cells, causing the cells to die. Thus, copper sulfate is effective in the destruction of fungi, algae and even snails. However, most fungicides used today are organic synthetic compounds [11].

\subsection{Non-systemic (Contact) Fungicides}

This type of fungicides has a preventive impact by killing or inhibiting fungi and fungal spores before the mycelia can grow and develop within the plant tissues [12], but have little or no effect once the fungus has entered or colonized host tissue. Additionally, while non-systemic fungicides generally remain on the surface of plants, they are potentially phytotoxic and can damage the plant when absorbed [11]. Contact action has derivatives dithiocarbamates acid, agents based on sulphur, copper, etc. Thus, this kind of fungicides can be used only as protectants. It is therefore also important to apply them on given plants before known infection period begins to decrease the chance of infection. Contact agents - such as zineb, polycarbonate, copper oxychloride, sulfur, mancozeb, bordeaux liquid and others are not able to cure already diseased plants. Despite their potential harm to plants, non-systemic pesticides are thought to be okay as they can be removed or flushed from the plant before harvest. This makes produce clean from pesticide chemical tainting and thus better for human consumption.

Typical examples of the primary contact fungicides are inorganic copper compounds such as Bordeaux mixture, copper carbonate, and inorganic sulphur in the form of elemental sulphur and lime sulphur [5]. The organic contact fungicides (e.g., thiram, ferbam, and ziram) play an important role in the comprehensive control of plant diseases since they are more efficient and less toxic than the inorganic compounds [13].

Contact fungicides are products suited for preventive (prophylactic) use as they work by contact action on the surface of the plant. Therefore, to protect new plant growth and renewal of the material washed off by rain or irrigation, or degraded by such environmental factors as wind and the amount of UV, repeated applications are necessary. The protective action of these fungicides does not exceed 10-12 days before the first heavy rain, after which the treatment is repeated. The number of treatments with a fungicide of contact action is 3 to 6 treatments per season. During processing, it is necessary to spray not only the surface of the leaves but the underside too, since many types of fungi begin to grow from the underside of the leaves. For example, for processing potatoes the rate of application may be every 7 days during the month [14].

Contact fungicides do not penetrate deeply in the plant tissue and are easily removed, leaving a clean product for consumption. They are effective with timely treatment and following instructions. Because of this, and due to relatively low prices (but it should be remembered that their consumption is much higher than systemic fungicides)), they are still extensively used for plant protection even though new, more potent fungicides are developed.

\subsection{Systemic Fungicides}

Systemic fungicides are absorbed by the plant and transported to the site of infection. These compounds can, therefore, kill the fungus after the mycelia have penetrated the parenchyma of the plant tissue, stopping the spread of infection [12]. Some systemic fungicides move within the plant only a short distance from the site of penetration. This is local-systemic fungicides. The dicarboximide fungicides are one example of this group [15]. The dicarboximide fungicides, iprodione, procymidone, vinclozolin, chlozolinate, and metomeclan are especially promising for the control of plant diseases caused by species of Botrytis, Sclerotinia, Monilinia, Alternaria, Sclerotium, and Phoma [16]. The mode of action of these compounds is apparently related to the inhibition of triglyceride biosynthesis in fungi [17].

Some locally systemic fungicides cross the leaf plate from one leaf surface to the other but do not spread inside the plant. Those fungicides are called translaminar, i.e. trifloxystrobin [18]. Systemic fungicides, which are called xylemmobile or acropetal systemics, move inside the water-conducting tissue (xylem), which raises them up in the transpiration flow, however, mobility within the plant is limited. For example, DMI fungicides are moderately mobile within plants. Others are very mobile and easily move 
around the xylem. The examples of systemic fungicides which are mobile in xylem are thiophanate-methyl and mefanox [19]. The third type of systemic fungicide is a phloem-mobile system, compound circulates in phloem out of the sheet where deposited upwards to the other leaves and downwards to the roots [11]. Only one example of this type of systemic exists among turfgrass fungicides: the phosphonates, which include fosetyl-Al and the phosphites [19].

Systemic fungicides can be used as protectants, eradicates, or both, and are the most recently developed and the most promising type of fungicides at the moment [5]. Though systemic fungicides usually have a particular location of the action, fungi may quickly develop resistance to them if they are managed inappropriately [20].

Highly specific modern fungicides block only one target in the pathogen (monospecific fungicides or single-site inhibitors). Deising and his colleagues [21] state that "examples of singlesite inhibitors are the benzimidazoles, phenylamides and strobilurins, released to the market in the late 1970es and the mid 1990es" [22].

Extensively used in agriculture are also benzimidazoles, a group of organic fungicides with systemic action. These types of compounds control a wide range of fungi at a comparatively low cost of treatment [23]. For example, benomyl is one of the most effective and extensively used benzimidazoles in crop protection [5]. The benzimidazoles benomyl, carbendazim, and thiabendazole and the phenylcarbamate diethofencarb specifically interfere with the formation of microtubules, which function in a variety of cellular processes, including mitosis and maintenance of the cell shape [24]. These fungicides bind specifically to protein subunits called tubulin and prevent their assembly from forming microtubules.

The main difference between the effects of systemic and contact fungicides is that the first one sometimes suppresses the fungus after infection of the plant, whereas the second one must be present on the plants surface before infecting. Gradually, since the 1960s, systemic fungicides replaced non-systemic non-systemic preparation, providing higher levels of plant protection [16]. However, compared with the nonsystemics, systemic fungicides are roughly twice as expensive regarding sales [25].

\section{BREADTH OF ACTIVITY}

Depending on the scope of their targets, fungicides can be classified as single-site or multi-site. Single-site fungicides are active against one point in one metabolic pathway of the fungus [18]. Examples of such fungicides can be various different drugs with one active ingredient, such as prothioconazole, pyraclostrobin, fludioxonil, the benzimidazoles (benomyl, thiophanatemethyl) and others. However, there are connections that are not very desirable to use alone, for example, azoxystrobin is recommended to use as a mixture with other fungicides having a different mechanism of action [26]. The probability of the pathogen's development resistance, in this case, is significantly reduced because resistant isolates to one fungicide will be killed by another fungicide. The effectiveness of this method can be demonstrated by Metalaxyl, phenylamide fungicide. When used as the sole compound in Ireland to combat pollution in potatoes (Phytophthora infestans) resistance developed within one growing season. However, in countries such as the UK where it was sold only as a mixture, resistance problems developed more slowly [19].

On the other hand, because of this specific activity, fungi are more likely to develop resistance to the fungicide [11].

Multi-site fungicides can target multiple locations (different metabolic pathways). But single-site fungicides are considered less toxic to plants. Older contact fungicides such as mancozeb, fluazinam etc have multi-site activity and affect many fungal species in different classes (Sclerotinia, Botrytis, Alternaria, Phytophthora, Peronospora) [27]. Due to the rise in the stringency and number of normative tests required to register a new active ingredient, fungicide manufacturers have found it easier to develop single-site systemics recently [25]. Consequently, fungicide resistance has become a more critical issue in disease regulation. Examples of narrow-spectrum fungicides can be Folplan and Karatan [28].

The active ingredient of Folplan - folpet derived phthalimide. Folplan, has a narrow spectrum of activity, suppresses the development of pathogens Phytophthora and other fungi, except for much national [28]. To broaden the spectrum of action can be mixed with other systemic fungicides, insecticides, which have no alkaline 
reaction [29]. Folplan registered and approved for use on potatoes and grapes. Suppresses the development of Phytophthora, Peronospora, Oidium, Botrytis. The flow rate - about $3.0 \mathrm{~kg} / \mathrm{ha}$. The maximum number of treatments - two for a season [28].

The active substance of Karatan - dinocap derived nitrophenol. It suppresses the development of powdery mildew pathogens and has acaricidal action. Ineffective against peronosporic fungi. Can be mixed with other fungicides and insectoacaricides, which have no alkaline reaction. The duration of the protective effect in the optimal concentrations of 10-15 days. It is advisable to use prophylactic. The fungicide does not penetrate the leaves and fruit, so it's easy to rinse them. Karatan is registered and approved for use on cucumbers the closed and open soil, grapes, Apple, pear. The flow rate of the drug is $0.5-2.0 \mathrm{l} / \mathrm{ha}$. The maximum number of treatments - three for season [28].

\section{APPLICATION METHODS}

Fungicides can be produced in the form of dust, granules, gas, but most often fluid. Depending on the type there are different methods of application:

1. Treat of planting material (mordanting). Fungicides can be applied in various solutions or incrustation of seeds, dry method or humidification, encapsulating or pelleting.

2. Application to the soil. This process is suitable when dealing with soil-borne pathogens. Most of these fungicides have low selectivity and thus eliminate not only bacteria and fungi but also the larvae of insect pests which could be of concern for environmental protection.

3. Spraying. The manual sprayers are used, as well as a specialized automobile or aircraft vehicles. Spraying can be carried out repeatedly in the rate of appearance of the young vegetative organs of the plant, the duration [30] of action of a fungicide, and the risk of re-infection [31].

Great importance in the success of seed protection is the correct timing of fungicide treatment. Thus, seed disinfectants are commonly used in packing material deposited in the late summer or autumn, and fungicides are used for spraying perennial plants during dormancy in late fall, winter or early spring, as they can be dangerous to growing plants [32], [33]. Currently, in addition to the use of the described methods to prevent spoilage during storage, fruit treatment by fungicides is also practised [34].

\section{ROLE OF FUNGICIDES IN DISEASE MANAGEMENT}

Forecasting systems are developed for many diseases based on an understanding of the environmental conditions favourable for pathogen development. Typically, these are based on temperature and relative humidity or leaf wetness in the area with a growing crop [35]. Threshold-based fungicide programs involve routinely scouting the crop for symptoms, then applying fungicides when the number of signs reaches a critical level beyond which the disease cannot be controlled adequately [25]. In general, the most crucial aspect of developing and using forecasting systems is the knowledge of the disease cycle of the pathogen. The disease cycle determines whether the disease is monocyclic (one generation per year) or polycyclic (multiple generations) and latent period (time between infection and symptom expression) is also essential aspect [36].

There are examples of an artificial neural network (ANN) capable of predicting diseases based on existing data. They perform extraordinarily complex calculations imitating biological in the real world without about course to exact quantitative. Back-propagation neural network (BPNN) is the most important and widely used one [37]. The RBF network is used in Mingwang Shi research, which is one of the new effective neural networks and is realized through a linear combination of nonlinear primary functions from the space $R^{N}$ into a spatial RM through nonlinear transformation. He applied the GM Model $(1,1)$ to predict plant diseases collected during the simulations. The results of the experiments show that the coincidence of the GM model parameter $(1,1)$ coincides with the standard deviation of the disease index and incidence. This indicates that the GM system $(1,1)$ is effective for the analysis of morbidity, and the parameters GM $(1,1)$ may well reflect the change in the incidence of plants [37].

Another interesting example of plant diseases prediction is the using of electric fields $[38,39]$. In the work of Marek Kuna-Broniowski and etc., this method is used to predict the spread of plant diseases from the Septoria by determining the 
splashing of raindrops. Most existing methods use climate conditions, calendar measurements, and disease cycles to predict infections [40]. However, it is important to take into account the spraying of rain droplets as a method of transporting spores to higher parts of plants and neighbouring plants. Measurements of the scattering range and the number of spray particles using an electric field are achieved using a measuring system that allows accurate and reliable measurement of the dispersion range of sprayed droplets [39].

Economic factors often influence the choice of fungicide and application timing. The most expensive fungicides and numerous applications are used on valuable plantings that might suffer a significant economic loss in the absence of treatment, for example, fruit trees [41]. The crop tolerance level, or detriment threshold, can change depending upon the stage of the crop development when attacked, crop management practices, climatic and location conditions [42].

It is important to use the correct type of fungicide at the right time of year because one of the fungicide side-effects is phytotoxicity, i.e. a toxic effect on (beneficial) plants. For example, trifloxystrobin, which is often applied to Vitis vinifera vines, can damage and even kill some trees of the genus Malus. However, trifloxystrobin is dangerous for particular grape cultivars but not others (can cause injury to Vitis labrusca) [8]. Some fungicides are even more specific, such as triazole + Qols that cannot be applied to glycine max later than during a growth stage known as R5 [27].

\section{THE MAIN CLASSES OF FUNGICIDE AND PLANT PHYSIOLOGICAL RESPONSES}

There are five main chemical classes of fungicides (Table 1). The largest group of them is triazoles. Fungicides of this class have been using against pathogens of various diseases of fruit and vegetable crops. Substances differ in the degree of activity, the spectrum of effects on pathogens, the rate of consumption, the grade of risk to ecosystems, the population and working personnel, the payback of the costs of their use. Despite the wide range of action, triazoles have disadvantages. The systematic use of preparation based on triazoles leads to the emergence of resistant fungal strains. For example, triadimefon does not completely inhibit the fungal germination of the genus Puccinia.

The widely accepted assumption that fungicide has low phytotoxicity has started to be outdated with the publication of more detailed analyses at the cell level that demonstrated several damages to the photosynthetic apparatus $[7,24]$.

Triazoles also have phytotoxicity to protected plants. In a significant amount, fungicides cause a retardant effect (impaired synthesis of gibberellins); violate the synthesis of sterols, reduce transpiration of plants [43]. Triadimenol and propiconazole delay the removal of the primary leaf and violate its geotropism in the processing of cereal seeds. Tebuconazole can pass into the retardant under unfavourable conditions (waterlogging of the soil, lack of moisture, low germination energy, etc.). The same properties are inherent in triticonazole, to a lesser extent - to other azoles. But as the review "Constraints on the evolution of azole resistance in plant pathogenic fungi" says, today, the azoles still apply in the fight against pathogens of many culture, including grains, fruits and vegetables, canola and soybeans, despite numerous reports of azole-resistant fungal strains [44].

The next well-known group of fungicides (over 30 years old) is phenylpyrrole. They are chemical analogues of the natural antifungal compound pyrrolnitrin [45]. Currently, fungicoxon is used as the active substance of fungicides. Phenylsilyl inhibits all stages of fungal development, germination of spores, lengthening of the embryonic tubes and mycelium growth. The observed consequences are swollen hyphae with increased branching and apical lysis, which indicate that phenylpyrls can act on the biosynthesis of the intragenic turgor and cell wall [46].

Recently strains resistant to fludioxonil have been isolated from B. cinerea populations in China at low levels $(<3 \%)$. They represent typical osmosensitivity and developmental defects of fludioxonil resistant mutants [47], which raises the question of their ability to compete with sensitive and severe strains and the selective pressure of fungicide treatments on these specific populations. Globally, there is no specific resistance to fludioxonil among grey mould populations that support the high efficacy of this fungicide [48]. 
Table 1. The major classes of fungicides and their effects

\begin{tabular}{|c|c|c|c|c|c|c|}
\hline Chemical class & Fungicides & $\begin{array}{l}\text { Mechanism of } \\
\text { action }\end{array}$ & Fungi & Resistance & Phytotoxicity & References \\
\hline Triazoles & $\begin{array}{l}\text { Tebuconazole, } \\
\text { prothioconazole, } \\
\text { diphenoconazole, } \\
\text { ciproconazole, } \\
\text { propiconazole, } \\
\text { epoxiconazole, } \\
\text { flutriafol, } \\
\text { triadimefon, } \\
\text { triticonazole, } \\
\text { diniconazole }\end{array}$ & $\begin{array}{l}\text { Inhibit sterol } \\
\text { biosynthesis }\end{array}$ & $\begin{array}{l}\text { Botrytis, Ustilago, } \\
\text { Cercospora, Tilletia } \\
\text { Zymoseptoria, } \\
\text { Fusarium, } \\
\text { Cochliobolus, } \\
\text { Erysiphe, Altemaria, } \\
\text { Puccinia, Septoria, } \\
\text { Pythium, Drechslera, } \\
\text { Pyrenophora, } \\
\text { Rhynchosporium, } \\
\text { Cladosporium, } \\
\text { Epicoccum, Phoma }\end{array}$ & $\begin{array}{l}\text { The systematic use of } \\
\text { drugs based on } \\
\text { triazoles causes } \\
\text { resistance. The } \\
\text { triadimefon does not } \\
\text { completely inhibit the } \\
\text { germination of conidia } \\
\text { and rust urediospores. }\end{array}$ & $\begin{array}{l}\text { There is a } \\
\text { violation of the } \\
\text { synthesis of } \\
\text { gibberellins } \\
\text { (retardant effect), } \\
\text { the synthesis of } \\
\text { sterols, a } \\
\text { decrease in } \\
\text { transpiration of } \\
\text { plants }\end{array}$ & {$[44,16,18,50,51]$} \\
\hline Phenylpyrroles & Fluodioxonyl & $\begin{array}{l}\text { Inhibit micellic } \\
\text { growth, reduce } \\
\text { glucose } \\
\text { phosphorylation } \\
\text { during cell } \\
\text { respiration, disrupt } \\
\text { the function of cell } \\
\text { membranes } \\
\end{array}$ & $\begin{array}{l}\text { Tilletia, Fusarium, } \\
\text { Ascochyta, Altemaria, } \\
\text { Fusarium, Aspergillus, } \\
\text { Rhizoctonia } \\
\text { Helminthosporium, }\end{array}$ & $\begin{array}{l}\text { Low risk of resistance } \\
\text { due to the mechanism } \\
\text { of action }\end{array}$ & $\begin{array}{l}\text { Decrease } \mathrm{CO}_{2} \\
\text { assimilation, } \\
\text { transpiration, } \\
\text { stomatal } \\
\text { conductance and } \\
\text { intercellular } \mathrm{CO}_{2} \\
\text { concentration }\end{array}$ & {$[7,25,45,46,47]$} \\
\hline Strobilurins & $\begin{array}{l}\text { Picoxystrobin, } \\
\text { fluoxastrobin, } \\
\text { azoxystrobin, } \\
\text { trifloxystrobin, } \\
\text { pyraclostrobin, } \\
\text { krezoksim-methyl }\end{array}$ & $\begin{array}{l}\text { Inhibit } \\
\text { mitochondrial } \\
\text { respiration by } \\
\text { blocking electron } \\
\text { transport in the } \\
\text { cytochrome } b \text { and } \\
c_{1} \text { chain }\end{array}$ & $\begin{array}{l}\text { Puccinia, Septoria, } \\
\text { Pyrenophora, } \\
\text { Alternaria, } \\
\text { Cladosporium, } \\
\text { Epicoccum, Botrytis, } \\
\text { Rhynchosporium, } \\
\text { Drechslera, Fusarium, } \\
\text { Rhizoctonia, Ustilago, } \\
\text { Erysiphe }\end{array}$ & $\begin{array}{l}\text { Field resistance was } \\
\text { recorded in Oidium } \\
\text { erysiphoides, Erysiphe } \\
\text { graminis, Botrytis } \\
\text { cineria. When } \\
\text { strobilurins inhibit the } \\
\text { activity of cytochrome } \\
\text { b, alternative pathways } \\
\text { of electron transport } \\
\text { can easily be activated }\end{array}$ & $\begin{array}{l}\text { In the plant are } \\
\text { rapidly hydrolyzed } \\
\text { by ether linkage. } \\
\text { During periods of } \\
\text { drought, damage } \\
\text { is exacerbated }\end{array}$ & {$[52,53,8,54]$} \\
\hline
\end{tabular}


Baibakova et al.; ARRB, 32(3): 1-16, 2019; Article no.ARRB.49787

\begin{tabular}{|c|c|c|c|c|c|c|}
\hline Chemical class & Fungicides & $\begin{array}{l}\text { Mechanism of } \\
\text { action }\end{array}$ & Fungi & Resistance & Phytotoxicity & References \\
\hline Benzimidazoles & $\begin{array}{l}\text { Prochloraz, } \\
\text { thiabendazole, } \\
\text { thiophanate-methyl, } \\
\text { benomyl, } \\
\text { carbendazim }\end{array}$ & $\begin{array}{l}\text { Inhibit the } \\
\text { synthesis of } \\
\text { ergosterol in the } \\
\text { fungal cell and } \\
\text { disrupt its life } \\
\text { activity }\end{array}$ & $\begin{array}{l}\text { Fusarium, Botrytis, } \\
\text { Sclerotmia, Septoria, } \\
\text { Uncinula, Erysiphe }\end{array}$ & $\begin{array}{l}\text { Stable pathogenic } \\
\text { strains: } \\
\text { Pseudocercosporella, } \\
\text { Septoria, Fusarium, } \\
\text { Erysipe, }\end{array}$ & $\begin{array}{l}\text { Decrease plant } \\
\text { biomass. induces } \\
\text { a considerable } \\
\text { reduction on the } \\
\text { chlorophyll a, } \\
\text { chlorophyll b, } \\
\text { carotenoids, and } \\
\text { the total pigments } \\
\text { content }\end{array}$ & {$[16,55,21]$} \\
\hline $\begin{array}{l}\text { Morpholines } \\
\text { (cinnamic acid } \\
\text { derivatives) }\end{array}$ & $\begin{array}{l}\text { Spiroxamine, } \\
\text { dimethomorph }\end{array}$ & $\begin{array}{l}\text { Prevent the } \\
\text { formation of } \\
\text { mycelium and } \\
\text { block the reduction } \\
\text { of the double } \\
\text { compound C-C } \\
\text { and ergosterol } \\
\text { synthesis }\end{array}$ & $\begin{array}{l}\text { Erysiphe, Uncinula, } \\
\text { Septoria, Puccinia }\end{array}$ & $\begin{array}{l}\text { Stable fungal strains } \\
\text { form slowly, fungicides } \\
\text { block the reduction } \\
\text { reactions in the } \\
\text { process of sterol } \\
\text { biosynthesis and } \\
\text { isomerization }\end{array}$ & $\begin{array}{l}\text { Decrease of the } \\
\text { sterols synthesis }\end{array}$ & {$[56,55]$} \\
\hline
\end{tabular}


To avoid the emergence of resistance to phenylpyrroles, combined preparations should be used or alternate with different mechanisms of action. In addition to problems with possible resistance, there is a risk of phytotoxic effects in relation to protecting plants [7]. For example, in research of Petit A.N, Fontaine F, Clement and Vaillant-Gaveau N [7] and also Saladin G, Magńe C, Cĺement C [24] about effects of fludioxonil in Vitis vinifera $L$. These reports have shown that application of fungicides has consequences for plant physiology, such as a plant growth reduction, perturbation of reproductive organ development, alteration of nitrogen, and/or carbon metabolism and limit photosynthetic activity $[7,49,24]$.

Saladin et al. reported that in vitro application of some fungicides, i.e. fludioxonil, and a systemic fungicide pyrimethanil, promoted different physiological responses of plants. Firstly, both fungicides decreased net $\mathrm{CO}_{2}$ assimilation, transpiration rate, stomatal conductance, and intercellular $\mathrm{CO}_{2}$ concentration; secondly, in the fruiting cuttings, the fungicides affected $\mathrm{CO}_{2}$ exchange neither transpiration rates [24].

Strobilurin group includes synthetic substances similar in structure to natural fungicidal toxins strobilurins $A$ and $B$, isolated from the culture of microorganisms Strobilurus tenacellus [52]. Strobilurins are recommended to be used first in the growing season because they rapidly reduce the ability of resistant to triazole forms to their development on leaves. In addition, the selection pressure is reduced, since the level of the inoculum is the lowest at the beginning of the growing season. Due to the wide range of activities and practical safety for the environment, strobilurins are considered to be the most significant group of fungicides that appeared after the preparations of the triazole classes. These substances can be attributed to biofungicides since they are of natural origin [53]. High resistance to strobilurins (for example, 200 times less sensitive to them in powdery mildew of wheat) is due to a one-point mutation in that part of the cytochrome $b$ molecule, which determines the binding of this enzyme to fungicides. At the same time, the active centre of the enzyme does not change, and the resistant (mutant) forms of fungi do not lose their viability as a result of mutation and the acquisition of resistance to strobilurins. It is also possible the cross-resistance between strobilurinsmethoxyacrylates, oximinoacetates and nonstrobilurins with a similar mechanism of action- oxazolidinediones. Resistance is registered in Oidium erysiphoides, Erysiphe graminis, Botrytis cinerea [57]. To prevent resistance, only 1-2 treatments (in some cases, three) at intervals of 14-16 days are permitted during the season and only preparation in the fungicide alternation system with a different mechanism of action from strobilurins [38] are allowed. For vegetable and fruit, it is triazoles, ethylenebisdithiocarbamates, preparations based on copper and sulfur. When processing annuals in the treated area, it is necessary to practice changing cultures [53].

Some reports suggested that the systemic fungicide strobilurin may improve the water status and stress management of plants under conditions of drought stress [29,58]. Nason Mark and his colleagues in their work 'Strobilurin fungicides induce changes in photosynthetic gas exchange that do not improve water use efficiency of plants grown under conditions of water stress' [59] showed that the application of beta-methoxyacrylate, a strobilurin fungicide, improve the water use efficiency only in wellwatered Triticum aestivum and Hordeum vulgare plants. However, when these plants were under drought stress, strobilurin strongly reduced net $\mathrm{CO}_{2}$ assimilation, intercellular $\mathrm{CO}_{2}$ concentration, transpiration rate, and rate of stomatal conductance to water. In this study, net $\mathrm{CO}_{2}$ assimilation reduction seems to be related to stomatal conductance decrease. It is possible that stomata respond to strobilurin-induced changes in mesophyll photosynthesis either by sensing changes in the intercellular $\mathrm{CO}_{2}$ concentration or by responding to the pool size of an unidentified C-fixing substrate. It is also possible that the effects of strobilurin fungicides are mediated via ABA-based chemical signaling [18].

The analysis of several chlorophylls a fluorescence parameter of plants treated with fungicides $[2,14,18,21]$ demonstrated that light reactions of photosynthesis are also sensitive to fungicide exposure. Bader and Abdel-Basset showed, for the first time, that fungicides of the triforine type (a systemic and contact fungicide) strongly inhibit electron-transport reactions of chloroplasts. Moreover, the application of systemic fungicides, benzimidazoles and triazole, and a dithiocarbamate contact fungicide affected the effective quantum yield of PSII as well as the maximal quantum efficiency of PSII (Fv/Fm). This reduction was attributed to the decrease in photochemical quenching (qP) [2,21]. In Glycine max, strobilurin fungicides application reduced 
the ratio of $\mathrm{Fv} / \mathrm{Fm}$. Strobilurin fungicides seem to block the transport of electrons between PSII and PSI by binding to the Qi site of the chloroplast cytochrome bf complex [18].

Benzimidazole formulations were among the first systemic fungicides to appear on the market. Benzimidazole derivatives are effective against diseases of vegetative organs, as well as a complex of phytopathogens transmitted between seeds, so they find wide application as seed disinfectants [27]. The narrow selectivity of the action contributes to a sufficiently rapid selection of resistant genotypes and the formation of a resistant population after a systematic (within 3-4 years) use of substantive of this group [5]. Several reports show a decrease in biomass production in fungicide-treated plants: benomyl, a systemic fungicide, reduced the growth of Gossypium hirsutum, Helianthus annuus, Cucumis sativus, Lactuca sativa, and Pinus taeda [60]. Moreover, the application of carbendazim (systemic benzimidazole fungicide) in Nicotiana tabacum affected negatively plant biomass [5].

Pigment biosynthesis is reported by Ahmed et al. [60] to be inhibited by benomyl. This fungicide induces a considerable reduction on the chlorophyll a, chlorophyll b, carotenoids, and the content of the total pigment of Helianthus annuus plants [60]. Similarly, the treatment of Vitis vinifera with fludioxonil and Nicotiana tabacum with carbendazim also decreases the chlorophyll and carotenoid content $[5,25]$. Van lersel, Bugbee, Changjun Chen and his colleagues reported leaf chlorosis after benomyl application on Impatiens walleriana, Cucumis sativus, Celosia plumosa Petunia hybrid, and Lycopersicon esculentum $[21,61]$.

There is also a phenomenon of cross-resistance. Fungi that are resistant to one fungicide are often also resistant to other fungicides from the same chemical class. Sometimes between fungicides from different chemical classes, there is a negative cross-resistance. For example, one such case was identified in the study of two major pathogens (Mycosphaerella graminicola and Tapesia acuformis) of winter wheat in France. Negative cross-resistance to edifenphos and several sterol biosynthesis inhibitors, such as prochloraz and fenpropimorph, was observed in strains resistant to fenhexylamide [57]. The reason for this phenomenon may be that a genetic modification that occurs under the action of a single fungicide and imparts resistance to it, makes the resistant isolate more susceptible to another fungicide [25].

Morpholines are a class of low-toxic and highly effective fungicides, one of the first groups of sterol synthesis inhibitors. They are part of the combined preparations. Although other inhibitors of sterol synthesis outperform the group of morpholines by economic parameters, these substances again acquire importance for the problem of the resistance to fungicides [62]. In contrast to triazoles, morpholines block the isomerization and reduction reactions in the process of sterols biosynthesis, therefore the populations of fungi that are resistant to them are formed much more slowly. According to the spectrum of action on pathogens, morpholines do not differ from triazoles but require higher application rates. Despite the slow development of resistant strains, there is a potential for dimethomorph to develop resistant strains of pathogens that do not have cross-resistance to phenylamides.

There are cases of phytotoxicity with substances from other chemical classes. In study Yuba R. Kandela, Daren S. Mueller and etc. [63] says that preemergence herbicides and seed treatment fluopyram each has led to increased phytotoxicity in the VC-V1 growth stage in soybean compared to the untreated control. Physiological studies after fungicide application on several species reported modifications of both photosynthetic activity and chlorophyll a fluorescence [24]. Decreased $\mathrm{CO}_{2}$ assimilation in fungicide-treated plants is attributed to both stomatal (due to stomatal closure) [2] and nonstomatal effects due to a disruption in the capacity of RuBisCO carboxylation, decrease of RuBisCO content, and/or reduction of the ribulose 1.5 bisphosphate regeneration $[7,18]$.

Modifications of dark respiration were reported after mancozeb (contact fungicide) and flusilazol (systemic fungicide) application in Malus domestica. The increase in dark respiration can be explained by additional energy requirement, metabolic breakdown of the compound, and/or activation of the alternative, cyanide-insensitive, respiration. Curiously, the treatment with strobilurin fungicides induced different responses: while in Triticum aestivum and in Spinacia oleracea plants respiration was inhibited $[29,64]$ in Triticum aestivum dark respiration was reduced [18].

The most crucial aspect of work of fungicides is their efficiency against fungal pathogens or their 
residues in crops [6,24]. Several reports found that some fungicides can improve plant defences through phytoalexin synthesis and cell wall lignification or stimulate enzymes involved in the synthesis of phenolic compounds [24,65]. Others describe the supposed protective role of fungicides for crops against various types of stress factors. Wu and Von Tiedemann [7,41] described the protective function of triazoles in Hordeum vulgare and Arachis hypogaea against ozone exposure or salt stress by stimulating antioxidative enzymes. Furthermore, azoxystrobin and epoxiconazole were shown to retard senescence of Triticum aestivum primarily due to an expansion of the antioxidative potential protecting the plants from damage by active oxygen species [41]. Muthukumarasamy and Panneerselvam described the induction of the synthesis of photosynthetic pigments and proteins in treated plants [66]. However, only small number of studies have considered the question of whether these products boost or inhibit physiological and metabolic activities in the plant tissues [5], and the negative impact of fungicides on photosynthesis, pigment content, growth, and alterations in the reproductive organs was poorly analyzed $[7,24]$.

The decrease in photosynthesis rate intensely influences plant biomass production and growth rates. Information about fungicide effects on plant physiology (especially on photosynthesis) is decisive for the understanding of the primary regulatory mechanisms and the phytotoxicity of a given compound [7].

\section{MYCORRHIZAL FUNGI RESPONSES}

Fungicidal compositions for seeds containing a multi-ingredient system are targeted at multiple metabolic processes. And many researchers in this field are concerned with the question: can these fungicides to inhibit inappropriate soil fungi, such as obligate plant symbiotic arbuscular mycorrhizal fungi (AMF).

Arbuscular mycorrhizal fungi are symbionts of plants, which interrelate with approximately $80 \%$ of plant species [27]. For example, multilateral interactions between roots and mycorrhizal fungi can have a synergistic effect on the growth and systemic priming of wheat [67]. These symbionts often have a beneficial effect on the host plant, increasing nutrient intake and tolerance to biotic and abiotic stresses, improving soil quality in cropping systems.
The study of Xue-Li He and his colleagues in the journal Huan Jing Ke Xue [68] says that in the treatment with benomyl, the content of $\mathrm{K}$ in the shoot and the $\mathrm{Fe}$ in the root decreased significantly in mycorrhizal plants; in the treatment with difenoconazole, the total $\mathrm{N}$ and $\mathrm{K}$ content in the shoot also decreased, $\mathrm{Ca}$ in the roots; mycorrhizal colonization, total $\mathrm{P}, \mathrm{K}$ and $\mathrm{Cu}$ content in the shoot, the total amount of $\mathrm{N}, \mathrm{Ca}$, $\mathrm{Zn}$ and $\mathrm{Fe}$ in the root was significantly reduced with fluosilazole. The inhibitory effect of flusilazole on the colonization of Glomus mosseae and the growth of Scutellaria baicalensis were higher than with difenoconazole and benomyl [68].

But in other studies, in the analysis of corn (Zea mays L.), soybean (Glycine max L.) and oats (Avena sativa L.) treated with azoxystrobin, fludioxonil, mekenoxane, trifloxystrobin, and pyraclostrobin, no found a significant effect on AM fungal colonization [69]. Fungicides were applied according to the recommended dosages. In small amounts, the following negative effects were observed. Corn treated by Cruiser Extreme had significantly lower $(P<0,05)$ colonization of AM fungi compared to the other two fungicides (Trilex, Stamina) and tended to decrease the colonization of $\mathrm{AM}$ corn roots as compared to controls $(P=0,08)$. The Cruiser Extreme consists of a locally systemic fungicide (azoxystrobin) inhibiting respiration, a systemic fungicide (mekenoxane) inhibiting the synthesis of nucleic acids, and a contact fungicide (fludioxonil), which prevents the transduction of cells [16].

However, in the analysis of soy, the same relation was not found. In oats, the results were lower than the rest, but not lower than the controls [34]. The differences in the colonization of $\mathrm{AM}$ fungal between fungicidal medication, apparently, are not related to a particular mode of action. There was no relationship between the treatment of fungicide and plant genotype during colonization of AM fungi or the content of plant nutrients [69]. The plant genotype has a consistent effect on the colonization of AM fungi and the nutrient content of plants.

Schreiner and Bethlenfalvay have shown that a higher variety of AMF can better withstand the negative effects of fungicides [70]. The essential role of fungicidal action on AMF can be played by their movement in the plant. As a rule, contact fungicides are less harmful than systemic fungicides when using seeds measured by 
sporulation, glomalin and biomass of the host plant [71].

Murillo-Williams and Pedersen found that fludioxonil in treated seed had a positive effect on the AMF colonization in soy (Glycine max L.) due to a decrease in competition with the aggressive pathogen Rhizoctonia spp. [72]. But in another case, fludioxonil had no significant effect on the colonization of AMF in onions [73]. Thus, the potential negative effects of systemic and contact fungicides on non-targeted, useful AMF are not fully understood and studied [71]. With the recent introduction of commercial modified AMF for large-scale crop production, understanding the effects of fungicides on these beneficial organisms can help minimize the unintentional interactions between fungicides and AMF.

\section{CONCLUSION}

Fungicides are widely used and have become the main means of inhibiting the growth of fungi and fungal spores due to their relatively low cost, high efficiency and ease of use.

However, despite the wide variety of existing products and various routes of use, the problem of the emergence of new fungicide-resistant strains of pathogens remains open. Available studies have demonstrated that fungicide application may impair photosynthesis, the synthesis of sterols, gibberellins, transpiration, reduce $\mathrm{CO}_{2}$ assimilation and biomass, influence on the content of the total pigment. However, reports on phytotoxicity are generally based on a few physiological parameters using a large variety of plant species and different types and concentrations of fungicides, leading in some cases to contradictory results. This significantly jeopardizes a comprehensive knowledge of the primary effects of fungicides on the photosynthesis and certainly deserves further investigation.

It may be worthwhile to study in more detail methods for predicting the spread of diseases and testing theories during the development of fungicides using machine learning (i.e. artificial neural network). And as attractive aspects for further fungicide study are such aspects as cross-resistance and negative cross-resistance of different chemical classes fungicides. This knowledge would be extremely useful when developing new preparations.
Furthermore, the problem of the negative impact of fungicides on the environment due to their high toxicity still remains unresolved. However, the situation can be improved with the use of new technologies and a deeper understanding of the fungicides mechanism of action. Because of it allows to create preparations with a lower content of active substance, but not less effective. The solution to that problem will provide benefits not only for plants yield but also for the environment and human health.

Concerns about the non-targeted effects of fungicides on AMF are mainly focused on the potential impact on natural AMF in integrated management systems. However, understanding the compatibility of fungicides used for seeds, not only with natural but with modified useful AMF, is important if we want to maximize the benefits of both, obtained from sowing crops.

\section{COMPETING INTERESTS}

Authors have declared that no competing interests exist.

\section{REFERENCES}

1. Rohr JR, Brown J, Battaglin WA, McMahon TA, Relyea RA. A pesticide paradox: Fungicides indirectly increase fungal infections. Ecological Applications. 2017; 27(8):2290-2302.

DOI: 10.1002/eap.1607

2. Xia XJ, Huang $Y Y$, Wang $L$, et al. Pesticides-induced depression of photosynthesis was alleviated by 24epibrassinolide pretreatment in Cucumis sativus L. Pesticide Biochemistry and Physiology. 2006;86(1):42-48.

DOI: 10.1016/J.PESTBP.2006.01.005

3. Marín S, Ramos AJ, Cano-Sancho G, Sanchis V. Reduction of mycotoxins and toxigenic fungi in the Mediterranean basin maize chain. Phytopathologia Mediterranea. 2012;51(1):93-118.

Available:www.fupress.com/pm

(Accessed January 10, 2018)

4. Forrer HR, Musa $T$, Schwab $F$, et al. Fusarium head blight control and prevention of mycotoxin contamination in wheat with botanicals and tannic acid. Toxins. 2014;6(3):830-849. DOI: $10.3390 /$ toxins6030830

5. Pablo C. García, Rosa M. Rivero, Juan M. Ruiz LR. The role of fungicides in the physiology of higher plants: Implications for 
defense responses. The Botanical Review. 2003;69(2):162-172.

DOI:10.1663/0006-

8101(2003)069[0162:TROFIT]2.0.CO;2.

6. Report on the pesticide residues monitoring programme: Quarter 12017. London; 2017.

7. Petit AN, Fontaine F, Clement, Christophe; Vaillant-Gaveau N. Photosynthesis limitations of grapevine after treatment with the fungicide fludioxonil. Agriculture and Food Chemistry. 2008;56:6761-6767.

DOI: $10.1021 / \mathrm{jf} 800919 \mathrm{u}$

8. Vincelli P. Qol (Strobilurin) Fungicides: Benefits and Risks. The Plant Health Instructor; 2002.

DOI: 10.1094/PHI-I-2002-0809-02

9. Southern AG. Liquid copper fungicide. New Jersey; 2015.

10. Hahn Matthias. The rising threat of fungicide resistance in plant pathogenic fungi: Botrytis as a case study. Journal of Chemical Biology. 2014;7(4):133-41.

DOI: 10.1007/s12154-014-0113-1

11. Lesemann SS, Schimpke S, Dunemann F, Deising HB. Mitochondrial heteroplasmy for the cytochrome $b$ gene Controls the level of strobilurin resistance in the apple powdery mildew fungus Podosphaera leucotricha (Ell. \&amp; Ev.) E.S. Salmon. Journal of Plant Diseases and Protection. 2006;113(6):259-266.

DOI: 10.1007/BF03356191

12. Oliver RP, Hewitt HG. Fungicides in crop protection. 2th Ed. CAB International; 2014.

13. Aynalem B, Assefa F. Effect of glyphosate and mancozeb on the rhizobia isolated from nodules of Vicia faba $L$. and on their N 2 -fixation, North Showa, Amhara Regional State, Ethiopia. Advances in Biology. 2017;2017:1-7.

DOI: $10.1155 / 2017 / 5864598$

14. Johnson DA, Hamm PB, Miller JS, State $W$. Fungicide application for management of potato late blight in the Columbia Basin; 2014.

Available:http://public.wsu.edu/ djohnsn/in dex_files/Paper4.pdf

(Accessed December 21, 2017)

15. González M., Caetano P. SME. Testing systemic fungicides for control of Phytophthora oak root disease. Forest Pathology. 2017;47(4):1-3.

DOI: $10.1111 /$ efp.12343

16. Dias Maria Celeste. Phytotoxicity: An overview of the physiological responses of plants exposed to fungicides. Journal of Botany. 2012;1-4.

DOI: $10.1155 / 2012 / 135479$

17. Borgers Marcel. Mechanism of Action of Antifungal Drugs, with Special Reference to the Imidazole Derivatives [with Discussion]. Reviews of Infectious Diseases. 1980;2:520-534.

18. Mueller DS. Fungicides: Terminology. Integrated Crop Management. 2006:120123.

Available:http://lib.dr.iastate.edu/cropnews( Accessed January 10, 2018)

19. Paul Vincelli, Bruce Clarke GM. Chemical Control of Turfgrass Diseases; 2017.

20. Lucas JA (John Alexander). Plant pathology and plant pathogens. John Wiley \& Sons; 2009.

21. Deising HB, Reimann S, Pascholati SF. Mechanisms and significance of fungicide resistance. Brazilian Journal of Microbiology. 2008;39(2):286-295. DOI:10.1590/S1517-83822008000200017

22. Miguez M, Reeve C, Wood PM, Hollomon DW. Alternative oxidase reduces the sensitivity ofMycosphaerella graminicola to $\mathrm{QO}$ f fungicides. Pest Management Science 2004; 60(1):3-7.

DOI: $10.1002 / p s .837$

23. Bernauer O, Gaines-Day H, Steffan S. Colonies of Bumble Bees (Bombus impatiens) produce fewer workers, less bee biomass, and have smaller mother queens following fungicide exposure. Insects. 2015;6(4):478-488.

DOI: 10.3390/insects6020478

24. Saladin Gaëlle, Magné Christian CC, Clément C. Effects of fludioxonil and pyrimethanil, two fungicides used against Botrytis cinerea, on carbohydrate physiology in Vitis vinifera L. Pest Management Science. 2003;59(10):10831092.

DOI: $10.1002 / p s .733$

25. McGrath MT. What are Fungicides? The Plant Health Instructor; 2004.

DOI: 10.1094/PHI-I-2004-0825-01

26. Jørgensen Lise Nistrup, Oliver Richard Peter, Heick Thies Marten. Occurrence and avoidance of fungicide resistance in cereal diseases. 2018;235-259.

27. Cameron J. Effects of Seed Applied Fungicide on arbuscular mycorrhizal colonization of South Dakota cultivars of Oat, Soybean, and Corn; 2016.

28. Ganiev MM, Nedorezkov VD. Chemical plant protection products. (A.S. 
Maksimova, ed). Moscow: Colossus; 2006. Russian.

29. Paranjape K, Gowariker V, Krishnamurthy VN, Gowariker S, KP. The pesticide encyclopedia. UK ed. Edi. London: CABI; 2014.

30. Woodward JE, Russell SA, Baring MR, Cason JM, Baughman TA. Effects of Fungicides, Time of Application, and Application Method on Control of Sclerotinia Blight in Peanut. International Journal of Agronomy. 2015;8.

DOI: $10.1155 / 2015 / 323465$

31. E. Lee Butler LPT. Method and timing of fungicide applications for control of spring dead spot in hybrid bermudagrass. Plant Health Progress; 2006.

DOI: 10.1094/PHP-2006-0901-01-RS

32. Hasan MA, Ahmed JU, Tofazzal H, Mian MAK, Haque MM. Evaluation of the physiological quality of wheat seed as influenced by high parent plant growth temperature. Journal of Crop Science and Biotechnology. 2013;16(1):69-74.

DOI: $10.1007 / \mathrm{s} 12892-010-0056-1$

33. Shuping DSS, Eloff JN. The use of plants to protect plants and food against fungal pathogens: A review. African journal of traditional, complementary, and alternative medicines. AJTCAM. 2017;14(4):120-127. DOI: 10.21010/ajtcam.v14i4.14

34. Clayton A. Hollier, Jeffrey W. Hoy, Christopher A. Clark, Charles Overstreet, Jaspreet Sidhu, Melanie L. Lewis Ivey, Raghuwinder Singh, Trey Price III, Mary Helen Ferguson, G. Boyd Padgett DG. Louisiana Plant Disease Management Guide. Louisiana; 2016.

35. Kerr Ailen, Keane Philip. Prediction of disease outbreaks. In: Brown JF, Ogle HJ eds., ed. Plant pathogens and diseases. Armidale, NSW: University of England Print. 1997;229-314.

36. Suffert F, Thompson RN. Some reasons why the latent period should not always be considered constant over the course of a plant disease epidemic. Plant Pathology. 2018;67(9):1831-1840.

DOI: $10.1111 /$ ppa.12894

37. Ming-wang Shi. Based on time series and RBF network plant disease forecasting. Procedia Engineering. 2011;15:23842387.

DOI: 10.1016/J.PROENG.2011.08.447

38. Benelli Jesse J. Non-target effects of strobilurin fungicide applications on creeping bentgrass putting greens during summer stress; 2013.

39. Kuna-Broniowski M, Makarski P, KunaBroniowska I. Application of electric fields as a method for plant disease forecasting. Agriculture and Agricultural Science Procedia. 2015;7:146-151.

DOI: 10.1016/J.AASPRO.2015.12.009

40. Donatelli M, Magarey RD, Bregaglio S, Willocquet L, Whish JPM, Savary S. Modelling the impacts of pests and diseases on agricultural systems. Agricultural Systems. 2017;155:213-224. DOI: 10.1016/J.AGSY.2017.01.019

41. Untiedt R, Blanke MM. Effects of fungicide and insecticide mixtures on apple tree canopy photosynthesis, dark respiration and carbon economy. Crop Protection. 2004;23(10):1001-1006.

DOI: 10.1016/j.cropro.2004.02.012

42. Kjøhl M, Nielsen A, Stenseth NC. Potential effects of climate change on crop pollination; 2011.

43. Tom Allen. Not everything is as it seems: Fungicide phytotoxicity and plant diseases I Mississippi Crop Situation. Mississippi Crop Situation; 2013.

Available:http://www.mississippicrops.com/2013/08/09/not-everything-isas-it-seems-fungicide-phytotoxicity-andplant-diseases/

(Accessed January 9, 2018)

44. Cools HJ, Hawkins NJ, Fraaije BA. Constraints on the evolution of azole resistance in plant pathogenic fungi. Plant Pathology. 2013;62:36-42.

DOI: $10.1111 /$ ppa.12128

45. Kilani J, Fillinger S. Phenylpyrroles: 30 Years, Two Molecules and (Nearly) No Resistance. Frontiers in Microbiology. 2016;7:2014.

DOI: $10.3389 /$ fmicb.2016.02014

46. Lew RR. Turgor and net ion flux responses to activation of the osmotic MAP kinase cascade by fludioxonil in the filamentous fungus Neurospora crassa. Fungal Genetics and Biology. 2010;47(8):721726.

DOI: 10.1016/J.FGB.2010.05.007

47. Ren $W$, Shao $W$, Han $X$, Zhou $M$, Chen C. Molecular and biochemical characterization of laboratory and field mutants of Botrytis cinerea resistant to fludioxonil. Plant Disease 2016; 100(7):1414-1423.

DOI: 10.1094/PDIS-11-15-1290-RE

48. Walker AS, Micoud A, Rémuson $F$, Grosman J, Gredt M, Leroux P. French 
vineyards provide information that opens ways for effective resistance management of Botrytis cinerea (grey mould). Pest Management Science. 2013;69(6):667678.

DOI: $10.1002 / p s .3506$

49. Leroux P. Recent Developments in the Mode of Action of Fungicides. Pesticide Science. 1996;47(2):191-197.

DOI:10.1002/(SICl)1096-

9063(199606)47:2<191::AID-

PS415>3.0.CO;2-I.

50. Ahemad M, Khan MS. Alleviation of fungicide-induced phytotoxicity in greengram [Vigna radiata (L.) Wilczek] using fungicide-tolerant and plant growth promoting Pseudomonas strain. Saudi Journal of Biological Sciences. 2012; 19(4):451-459.

DOI: 10.1016/J.SJBS.2012.06.003

51. Costa AV, Oliveira MVL de, Pinto RT, et al. Synthesis of novel glycerol-derived 1,2,3triazoles and evaluation of their fungicide, phytotoxic and cytotoxic activities. Molecules. 2017;22(10):1666.

DOI: $10.3390 /$ molecules22101666.

52. Balba $H$. Review of strobilurin fungicide chemicals. Journal of Environmental Science and Health, Part B. 2007; 42(4):441-451.

DOI: $10.1080 / 03601230701316465$

53. Reddy PP. Strobilurin Fungicides. In: Recent advances in crop protection. New Delhi: Springer India. 2012;185-200.

54. Wojdyła AT. Influence of strobilurin compounds on the development of Puccinia horiana. Communications in Agricultural and Applied Biological Sciences. 2007; 72(4):961-6.

Available:http://www.ncbi.nlm.nih.gov/pub $\mathrm{med} / 18396835$

(Accessed January 23, 2018)

55. Isaac S. Fungal-plant interactions. 1. ed. London: Chapman \& Hall; 1992.

56. Biol TJ, Jităreanu $A$, Pădureanu $S$, Tătărîngă G, Tuchiluș C, Stănescu U. Evaluation of phytotoxic and mutagenic effects of some cinnamic acid derivatives using the Triticum test. Turkish Journal of Biology. 2013:748-756.

DOI: 10.3906/biy-1304-39

57. Leroux P, Chapeland F, Arnold A, Gredt M. New cases of negative cross-resistance between fungicides, including sterol biosynthesis inhibitors. Journal of General Plant Pathology. 2000;66(1):75-81. DOI: $10.1007 /$ PL00012925
58. Barr CM, Neiman M, Taylor DR. Inheritance and recombination of mitochondrial genomes in plants, fungi and animals. New Phytologist 2005;168(1):39_ 50 . DOI: 10.1111/j.1469-8137.2005.01492.x

59. Nason MA, Farrar J, Bartlett D. Strobilurin fungicides induce changes in photosynthetic gas exchange that do not improve water use efficiency of plants grown under conditions of water stress. Pest Management Science Pest Manag Sci. 2007;63:1191-1200.

DOI: $10.1002 / p s .1443$

60. Hunsche M, Damerow L, Schmitz-Eiberger M, Noga G. Mancozeb wash-off from apple seedlings by simulated rainfall as affected by drying time of fungicide deposit and rain characteristics. Crop Protection. 2007; 26(5):768-774.

DOI: 10.1016/j.cropro.2006.07.003

61. Changjun Chen, Jianxin Wang, Qingquan Luo SY, Mingguo Z. Characterization and fitness of carbendazim-resistant strains ofFusarium graminearum (wheat scab). Pest Management Science. 2007;63(12): 1201-1207.

DOI: $10.1002 / p s .1449$

62. Lamberth C. Morpholine fungicides for the treatment of powdery mildew. In: Bioactive Heterocyclic Compound Classes. Weinheim, Germany: Wiley-VCH Verlag GmbH \& Co. KGaA. 2012;119-127.

63. Kandel YR, Mueller DS, Legleiter T, Johnson WG, Young BG, Wise KA. Impact of fluopyram fungicide and preemergence herbicides on soybean injury, population, sudden death syndrome, and yield. Crop Protection. 2018;106:103-109.

DOI: 10.1016/j.cropro.2017.12.009

64. Pantazopoulou A, Diallinas G. Fungal nucleobase transporters. FEMS Microbiology Reviews. 2007;31(6):657675.

DOI: 10.1111/j.1574-6976.2007.00083.x

65. War AR, Paulraj MG, Ahmad T, et al. Mechanisms of plant defense against insect herbivores. Plant Signaling \& Behavior. 2012;7(10):1306-20.

DOI: $10.4161 / p s b .21663$.

66. Indian Council Of Agricultural research. Handbook of agriculture. $6^{\text {th }}$ ed. New Delhi: Directorate of Information and Publications of Agriculture, Indian Council of Agricultural Research; 2011. 
67. Pérez-de-Luque $A$, Tille $S$, Johnson I, Pascual-Pardo D, Ton J, Cameron DD. The interactive effects of arbuscular mycorrhiza and plant growth-promoting rhizobacteria synergistically enhance host plant defences against pathogens. Scientific Reports. 2017;7(1).

DOI: $10.1038 / s 41598-017-16697-4$

68. He, Xue-Li, Wang P, Ma L, Meng JJ. Effects of three fungicides on arbuscular mycorrhizal fungal infection and growth of Scutellaria baicalensis Georgi. Huan Jing Ke Xue= Huanjing Kexue. 2012; 33(3): 987-91.

Available:http://www.ncbi.nlm.nih.gov/pub $\mathrm{med} / 22624398$

(Accessed January 18, 2018)

69. Doe J. Arbuscular mycorrhizal fungi not inhibited by seed-applied fungicides. CSA News. 2017;62(7):12.

DOI: $10.2134 /$ csa2017.62.0713

70. Schreiner RP, Bethlenfalvay GJ. Plant and soil response to single and mixed species of arbuscular mycorrhizal fungi under fungicide stress. Applied Soil Ecology. 1997;7:93-102.
Available:http://citeseerx.ist.psu.edu/viewd oc/download?doi=10.1.1.579.3176\&rep=re p1\&type $=p d f$ (Accessed January 22, 2018)

71. Hongyan, Germida JJ, Walley FL. Suppressive effects of seed-applied fungicides on arbuscular mycorrhizal fungi (AMF) differ with fungicide mode of action and AMF species. Applied Soil Ecology. 2013;72:22-30.

Available:http://agris.fao.org/agrissearch/search.do?recordID=US201400165 252

(Accessed January 22, 2018)

72. Murillo-Williams A, Pedersen P. Arbuscular mycorrhizal colonization response to three seed-applied fungicides. Agronomy Journal. 2008;100(3):795.

DOI: 10.2134/agronj2007.0142.

73. Hernández-Dorrego $\mathrm{A}$, Mestre-Parés J. Evaluation of some fungicides on mycorrhizal symbiosis between two Glomus species from commercial inocula and Allium porrum L. seedlings. Spanish Journal of Agricultural Research. 2010; 8(S1):43.

DOI: $10.5424 /$ sjar/201008S1-1222

(c) 2019 Baibakova et al.; This is an Open Access article distributed under the terms of the Creative Commons Attribution License (http://creativecommons.org/licenses/by/4.0), which permits unrestricted use, distribution, and reproduction in any medium, provided the original work is properly cited.

Peer-review history:

The peer review history for this paper can be accessed here: http://www.sdiarticle3.com/review-history/49787 